Available online at http://jgu.garmian.edu.krd

Journal of University of Garmian

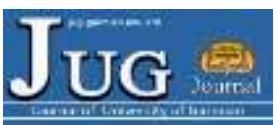

https://doi.org/10.24271/garmian.207020

\title{
The impact of Inflation and Oil price on Exchange rate for $(1977$ - 2019): Evidence from New Zealand
}

\author{
BESAR IBRAHIM MOHAMMED
}

Paitaxt Private Institute

\section{Article Info}

Received: January, 2020

Revised:February,2020

Accepted: March ,2020

\section{Keywords}

Inflation, oil price, exchange rate, economic growth, VAR Model

\section{Corresponding Author}

ban.shahab@garmian.edu.krd

\begin{abstract}
The exchange rate movements have been found with impacts on macroeconomic variables empirically. This paper aims to analyse the impact of three identified macroeconomic variables (oil price, inflation, economic growth) on the exchange rate in New Zealand. This study uses the secondary data available at the Central Bank of New Zealand and has included data only for a time from1977 to 2016. The exogenous variables included in this study are oil price, inflation, and economic growth while the exchange rate is the endogenous variable. The value at risk (VAR) model has been found best suited for the purpose of our study because it allows time series analysis. It was found that there was negative impact of inflation on NZ Dollar, but it was quantitatively significant because $1 \%$ increase in CPI resulted in $0.505 \%$ depreciation in the exchange rate. The oil price was found with positive impact on NZ Dollar value because $1 \%$ appreciation in the oil price resulted in $0.117 \%$ depreciation in NZ Dollar. Also, the significant impact of GDP growth on the exchange rate was found when $1 \%$ increase in GDP caused $0.568 \%$ appreciation in exchange rate. These findings suggest that the selected macroeconomic variables produced statistically significant impact on the exchange rate.
\end{abstract}




\section{1-Introduction}

In today's postmodern world where the globalisation has internationalised the economic landscape, the trade no longer bears any boundaries. With this ever-expanding outreach of international trade, the contrasting value of any particular country's currency against other currencies which is referred to as the exchange rate (Shapiro \& Hanouna, 2019) is of critical importance in evaluating global competitiveness. Allen and Gale (2004) have argued that the fluctuations in exchange rate set the direction and volume of foreign trade. For New Zealand which is a developed country and is ranked higher for its international trade competitiveness, it has been reported that the impact of exchange rate movements on the macroeconomic variables is evident from the correlation between the potential of impact and the resulting economic adjustments (Cassino et al., 2013). However, there are no sufficient empirical evidence available that can corroborate this claim. This inspires the objective of the current study where New Zealand has been selected as the setting to evaluate the impact of selected macroeconomic variables on the exchange rate.

The macroeconomic variables including oil price, inflation, and economic growth are considered to impact the exchange rate randomly in a country. Therefore, the volatility of the exchange rate is contingent upon the macroeconomic indicators of the country
(Kočenda \& Valachy, 2006). However, this variation in the exchange rate is not same for every country. The determinants of the exchange rate are same as of the economy while the impact of the macroeconomic variables on the exchange rate is not similar for developing and developed countries. On the other hand, the macroeconomic variables are responsive to fluctuations in the exchange rate (Ramasamy \& Abar, 2015).

The main objective of the current study is to determine the impact of three selected macroeconomic variables (oil price, inflation, and economic growth) on the exchange rate in the setting of New Zealand. This study will analyse the secondary data available at the Central Bank of New Zealand and will include data only for a period between 1977 and 2016. Given the limited empirical evidence from New Zealand, this study will conduct time series macroeconomic analysis for the longer period. For each of three macroeconomic variables, the current study has undertaken extensive discussion of empirical evidence within the literature review.

\section{2- Literature Review}

The empirical literature presents the evidence that can be related to the objective of this study. For this purpose, the literature discussing the impacts of exchange rate has been reviewed to justify the selection of three macroeconomic variables. However, there are no sufficient empirical evidence available for New 
Zealand in particular among other oil importing countries. This provides the rationale of the current study that seeks to analyse the impact of three selected variables on the exchange rate in New Zealand - an oil-importing country.

Oil remains the crucial commodity with demonstrated impact on the global economy. Among other macroeconomic variables, the impact of the oil price on the exchange rate has been investigated in multiple empirical studies (Alagidede et al., 2011; Amano \& Van Norden, 1998; Gan et al., 2006; Uddin et al., 2013). However, the empirical literature could not develop a consensus whether the impact of the oil price on the exchange rate is significant or insignificant. The conflicting findings emerged when some of the studies (Aliyu, 2012; Olomola $\&$ Adejumo, 2006) found significant while other studies (Hassan \& Zaman, 2012; Tiwari \& Olayeni, 2013) reported insignificant impacts of the oil price on the exchange rate in various developing countries including India, Pakistan and Nigeria. Another key dimension of this study is underscored by investigating whether the impact of oil price on the exchange rate bears any difference for oil-importing and oilexporting countries. This was responded in a recent study (Yang et al., 2017) which found no impact of the oil price on the exchange rate in oil-exporting countries but could not present a conclusive view for the oil-importing countries.

Exchange rate movements are not a silver bullet for understanding or forecasting the price of oil-and vice versa-and neither is a substitute for supply or demand factors. However, each contains potentially useful information for forecasting the other and should be considered, particularly over the short run. The oil price-exchange rate relationship is evolving over time and has recently become more volatile. The change in monetary policy and the financialization of commodity markets offer potential explanations for the intensified relationship. It remains to be seen whether the intensity of the link is affected by the proposed exit of unconventional monetary policy. From a policy perspective, an important question besides assessing flexible exchange rates is whether oil-exporting or oil-importing countries should be in favour of fixed or flexible exchange rate arrangements. There is strong evidence that oil prices and exchange rates are related over the long run. There is also a fair amount of evidence for various short-run linkages and spill-over between both markets at daily and monthly frequencies. The inverse causality from US dollar depreciations to increases in the price of oil often materializes at a daily frequency or over a few months (Beckmann et al., 2020).

Inflation is another macroeconomic variable that has been keenly evaluated for its impacts on the exchange rate (Svensson, 2000). The impact of inflation on the currency value and foreign exchange rate is diversely distinct for Asian and developed countries. For instance, it was found that the inflation was more responsive to fluctuation in exchange rates than in Asia and industrialized countries (Kamin \& 
Klau, 2003). On the contrary, no significant impact of inflation on the exchange rate could be determined in another study (Mohd et al., 2016).

The monetary policy is required to reflect on exchange rate movement because the domestic inflation is fundamentally driven by the appreciation and deprecation in the currency value and is thereby influenced largely by the domestic demand and supply shocks (Ball, 1999). On the contrary, it has also been argued that the industrialised nations may develop their monetary policies while being influenced by the exchange rate movements but the quantitative value of this causal link is insignificant (Clarida et al., 1998). In a structural analysis, it has been established that the central bank of New Zealand is not responsive to exchange rate movements and hence, the causal link between the inflation and the exchange rate could not be developed for the country under discussion (Lubik \& Schorfheide, 2007). These empirical evidences provide the basis of developing the hypothesis that the inflation has no impact on the exchange rate in New Zealand.

Like other macroeconomic variables, the literature seems divided on the potential impact of the economic growth on the exchange rate. For instance, the undervalued exchange rate was found as the predictor of the economic growth (Rodrik, 2008). On the contrary, it has also been found that an asymmetry exists between the currency depreciation and the economic growth if the undervaluation is treated in isolation (Nouira \& Sekkat, 2012). This varying impact of the economic growth on the exchange rate is explained through the Balassa-Sameulson effect (Égert et al., 2003).

Theoretically, it has been affirmed that there is a positive relationship between GDP growth rate and exchange rate. Some of the exchange rate determination theories such as the monetary approach to exchange rates predict that higher growth rates in a country lead to an appreciation of this country's currency. However, according to some other scholars, there is no causal relationship between GDP growth and exchange rates. But they are correlated. There are some relationships between GDP and Exchange Rates, but it depends of time period you observed. Sometimes it could be very strong relationship and sometimes it could be soft. It is not the same for every country because there is a different in monetary policy and impact monetary policy on FX, and another factor can have a different effect on FX (Habib et al., 2017).

\section{3- Data and Methodology}

In this project, data are obtained from the central bank of New Zealand [Reserve Bank of New Zealand] and OPEC website. Time span covers by annual data from 1977 to 2016 for all variables of the study. The series are also transformed to logarithmic forms for normalising the distribution of variables and to correct the bias which is expected in regression estimates (Beauchamp \& Olson, 1973). The methodology of the current study is inspired by 
the basic econometric principles (Gujarati, 2004).

The model of the study is emphasized as follow:

$$
\begin{gathered}
E X_{i t}=B_{0}+B_{1}+C P I_{i t}+B 2 O^{O I L} L_{i t} \\
+B_{3} G D P_{i t}+u_{i t}
\end{gathered}
$$

Where EX stands for New Zealand Dollar to US Dollar NZD/USD at time $t$, CPI is consumption price index of New Zealand at time $t$, and OIL is Crude Oil WTI FOB Cushing U\$/BBL at time $t$, GDP stands for the economic growth in New Zealand at time $t$ and $\mathrm{U}$ is the error terms.

For determining how the exchange rate movements in New Zealand responded to three identified macroeconomic variables, the vector autoregressive model (VAR) model was used while applying short-term restrictions (Juselius, 2006). There are multiple reasons that justify the use of VAR model. Firstly, this model has been widely applied for determining the impact of monetary policy upon the economy. This has also been underscored in the standard theory which postulates that the tightened monetary policy results in the increase of currency value immediately followed by the depreciation of the currency. The empirical studies investigating the impact of monetary policy on the exchange rate have predominantly used VAR model (Jääskelä \& Jennings, 2011). Secondly, VAR models are preferred over ARDL when the analysis involves time series (Keating, 1990). Since the current study has stipulated the duration between 1997 and 2016 for evaluating the impacts, VAR model is best-fit regression model.
While keeping in line with the objective of the current, three selected macroeconomic variables including oil price, inflation and economic growth have been characterised as the endogenous variables and the exchange rate is identified as the endogenous variable (Bjørnland \& Halvorsen, 2014), it is believed that the VAR model will be useful for determining the causal link between the exogenous and endogenous variables. For inflation, the annual changes in CPI were calculated because the annual inflation measure is the simple and direct approach to estimate the appreciation and depreciation of the exchange rate.

\section{4-The Empirical Results 4.1. Descriptive Statistics}

As mentioned earlier, the data collected from Reserve Bank of New Zealand and OPEC website for the time series between 1997 and 2016 has been analysed statistically using VAR model. The NZD currency value has been contrasted against the value USD to determine their impact on three selected macroeconomic variables namely CPI, oil, and GDP.

Table 1: Descriptive Statistics of Exchange Rate Responses to Macroeconomic Variables

\begin{tabular}{|l|c|c|c|c|}
\hline & NZD_USD & CPI & OIL & GDP \\
\hline Mean & 0.673390 & 69.52112 & 38.54025 & $1.10 \mathrm{E}+11$ \\
\hline Median & 0.651150 & 73.74752 & 27.85000 & $1.03 \mathrm{E}+11$ \\
\hline Maximum & 1.054700 & 109.2259 & 109.4500 & $1.73 \mathrm{E}+11$ \\
\hline Minimum & 0.415700 & 15.75873 & 12.28000 & $6.71 \mathrm{E}+10$ \\
\hline Std. Dev. & 0.153976 & 27.94827 & 29.29342 & $3.28 \mathrm{E}+10$ \\
\hline Skewness & 0.646434 & -0.416344 & 1.315737 & 0.360479 \\
\hline Kurtosis & 3.019359 & 2.146301 & 3.464485 & 1.716441 \\
\hline Jarque-Bera & 2.786471 & 2.370285 & 11.90066 & 3.612177 \\
\hline Probability & $\mathbf{0 . 2 4 8 2 7 1}$ & $\mathbf{0 . 3 0 5 7 0 3}$ & $\mathbf{0 . 0 0 2 6 0 5}$ & $\mathbf{0 . 1 6 4 2 9 6}$ \\
\hline Observations & 40 & 40 & 40 & 40 \\
\hline
\end{tabular}


As it is evident that all the variables are normally distributed except the oil prices which was also found in previous studies where the oil prices were found positively linked to exchange rate (Aliyu, 2012; Olomola \& Adejumo, 2006). However, the deviation in the oil price variable measured in the current study was the outcome of the exchange rate movements which may be attributed with short-term changes in oil price and the frequent fluctuations in stock exchange. The probability calculated below 0.05 can also be attributed with frequent changes in the oil prices which represents higher uncertainty.

\subsection{Regression Estimation}

Table 2: Regression Output of Exchange Rate

\begin{tabular}{|c|r|c|r|}
\hline Variable & Coefficient & t-Statistic & \multicolumn{1}{|c|}{ Prob. } \\
\hline LNCPI & -0.505595 & -4.412600 & 0.0001 \\
\hline LNOIL & 0.117645 & 1.867362 & 0.0700 \\
\hline LNGDP & 0.568201 & 2.197289 & 0.0345 \\
\hline C & -13.15437 & -2.192029 & 0.0349 \\
\hline & & R-squared & $\mathbf{0 . 5 1 4 5 2 9}$ \\
\hline & & $\begin{array}{l}\text { Adjusted } \\
\text { R-squared }\end{array}$ & $\mathbf{0 . 4 7 4 0 7 3}$ \\
\hline & & F-statistic & $\mathbf{1 2 . 7 1 8 2 5}$ \\
\hline & $\begin{array}{l}\text { Prob.(F- } \\
\text { statistic) }\end{array}$ & $\mathbf{0 . 0 0 0 0 0 8}$ \\
\hline & $\begin{array}{l}\text { Durbin- } \\
\text { Watson } \\
\text { stat }\end{array}$ & $\mathbf{0 . 7 1 7 7 7 9}$ \\
\hline
\end{tabular}

In this project, it has been consistently noticed that the uncertainty surrounding the oil price fluctuations have resulted in higher than usual probability. Despite the transformation of logarithmic forms, the autocorrelation problem requires to be fixed. As reported in the table 2, the coefficients of LNCPI, LNOIL and LNGDP are significant at 1\%,10\% and 5\% level of significance, respectively. That is why we reject the null hypothesis as the coefficients are zero as given below:

$$
\begin{aligned}
& \mathbf{H}_{\mathbf{0}}: \boldsymbol{\beta}_{\boldsymbol{i}}=\mathbf{0} \\
& \mathbf{H}_{\mathbf{1}}: \boldsymbol{\beta}_{\boldsymbol{i}} \neq \mathbf{0}
\end{aligned}
$$

The findings indicate that the impact of inflation on the New Zealand dollar is negative and statistically significant that is holding other variables constant, as CPI increases by one percent the exchange rate depreciates by about $0.505 \%$. The impact of oil prices on the New Zealand dollar is positive and statistically significant that is holding other variables constant, if oil price increases by $1 \%$ the New Zealand dollar appreciates by $0.117 \%$. The impact of economic growth found to be positive and statistically significant precisely if GDP increases by $1 \%$ the exchange rate will appreciate by $0.568 \%$ assuming other variables constant. Moreover, the intercept value is 13.154 and statistically significant.

$\mathrm{R}$-squared which measures the goodness of fit is around 0.515 which is quite lower than expected. However, this still suggests that $51.5 \%$ of the variation in New Zealand Dollar can be explained by inflation rate, oil prices and GDP. F-statistic is also significant at $1 \%$ level of significance, that is all CPI, OIL prices and GDP are jointly affecting the exchange rate. Thus, the hypothesis for F-test forms as below:

$$
\begin{gathered}
\mathrm{H}_{0}: \beta_{0}=\beta_{1}=\beta_{2}=0 \\
\mathrm{H}_{1}: \text { At least one of them } \neq \text { zero }
\end{gathered}
$$


Multicollinearity is one of the fundamental assumptions of the classical linear regression model which should be not ignored. The problem occurs when the independent variables are highly correlated typically by more than $90 \%$. The existence of the multicollinearity problem violates the CLRM assumptions and consequently our model is not BEST. As presented in table 3, the model of this project is suffering from multicollinearity problem as LNGDP and LNCPI are highly correlated.

Table 3: Correlation Matrix of Exchange Rate Impact

\begin{tabular}{|c|c|c|c|c|}
\hline & LNEX & LNCPI & LNOIL & LNGDP \\
\hline LNEX & 1.000000 & & & \\
\hline LNCPI & -0.367907 & 1.000000 & & \\
\hline LNOIL & 0.310058 & 0.487351 & 1.000000 & \\
\hline LNGDP & -0.049280 & 0.879484 & 0.721967 & 1.000000 \\
\hline
\end{tabular}

\subsection{Homoscedasticity}

The test of the homoscedasticity is another major assumption of CLRM that cannot be avoided. The null and alternative hypothesis shapes as bellow:

\section{$\mathrm{H}_{0}$ : there is no Heteroscedasticity} $\mathrm{H}_{1}$ : there is Heteroscedasticity

Table 4: Heteroskedasticity Test: Breusch-PaganGodfrey

\begin{tabular}{|c|c|c|c|}
\hline F-statistic & 0.121441 & Prob. F $(3,36)$ & 0.9469 \\
\hline $\begin{array}{l}\text { Obs*R- } \\
\text { squared }\end{array}$ & 0.400748 & $\begin{array}{l}\text { Prob. Chi- } \\
\text { Square(3) }\end{array}$ & 0.9401 \\
\hline
\end{tabular}

Based on the regression estimation, the model of this study could not demonstrate strength particularly when the probability was lower than expected. This, however, encourages further insights into how the fluctuating oil prices can impact the exchange rate in the modern days. Therefore, the mean and variances of the residuals of all the observations cannot be considered consistent with the lapse of time.

\subsection{Autocorrelation}

$$
\text { The problem of autocorrelation is }
$$
another violation of CLRM assumptions that's the residuals are serially correlated which they are not supposed to be. It can be detected by using Durbin-Watson Statistics criteria which is 0.717779 in our model indicates for positive autocorrelation. Or it can be conducted through Breusch-Godfrey Serial Correlation LM Test as it is already tested and reported in the table 5. The hypotheses of Breusch-Godfrey Serial Correlation test are:

\section{$\mathrm{H}_{0}$ : there is no Serial Correlation $\mathrm{H}_{1}$ : there is Serial Correlation}

Table 5: Autocorrelation Tests

\begin{tabular}{|c|c|c|c|}
\hline F-statistic & 13.41508 & Prob. F(2,34) & $\mathbf{0 . 0 0 0 1}$ \\
\hline $\begin{array}{c}\text { Obs*R- } \\
\text { squared }\end{array}$ & 17.64267 & Prob. Chi- & \\
& Square(2) & $\mathbf{0 . 0 0 0 1}$ \\
\hline
\end{tabular}

Unfortunately, since the F-value and Obs*Rsuqared value are strongly significant at $1 \%$ level of significant we reject the null hypothesis which means we have autocorrelation problem. This may be addressed in a future study with the inclusion of the larger sample size. 


\section{5- Conclusion}

Given the aim of the current study which was to analyse the impact of the oil price, inflation and economic growth on the exchange rate, the study could demonstrate valuable findings as far as the exchange rate movements are concerned. It is found that though there was negative causal link between inflation and NZ Dollar, but it was quantitatively significant because 1 percent increase in CPI resulted in $0.505 \%$ depreciation in the exchange rate. In contrary to our hypothesis, the oil price was found with positive impact on NZ Dollar value because $1 \%$ increase in the oil price resulted in $0.117 \%$ depreciation of NZ Dollar. Also, a significant causal link was found between the GDP growth and the exchange rate when it was observed that $1 \%$ increase in GDP caused $0.568 \%$ appreciation in exchange rate. These findings suggest that the exchange rate movements have sharp and significant impacts on macroeconomic variables in New Zealand and thereby, it is hard to assume that the monetary policy of the country does not consider their influences for controlling the central bank fiscal policies.

The model of this study, however, is subject to limitations in terms of significant coefficients of the variables, R-squared, F-statistic and homoscedasticity. The model has two significant problems which are autocorrelation and multicollinearity. Therefore, this model is incapable of inference and is considered inefficient. Consequently, it's not possible to make any reliable economic estimation of the impact of inflation, oil prices and economic growth on NZD/USD through the presented model of this study. It is recommended that the monetary policy of the country should not be tightened further to bear any exchange rate shocks particularly responsive to the increasingly fluctuating oil prices because this may lead to aggravation of uncertainty further.

The current study has certain limitations. The findings of the current study cannot be considered for other macroeconomic variables. The findings pertinent to the oil prices cannot be utilised for understanding the exchange rate movements and their impact. Any future research overcoming the autocorrelation error may demonstrate an effective approach of understanding the macroeconomic impacts. 


\section{References}

Alagidede, P., Panagiotidis, T., \& Zhang, X. (2011). Causal relationship between stock prices and exchange rates. Journal of International Trade and Economic Development. https://doi.org/10.1080/09638199.2011.538186

Aliyu, S. R. U. (2012). Impact of Oil Price Shock and Exchange Rate on Economic Growth in Nigeria: An Empirical Investigation. In Research Journal of International Studies.

Allen, F., \& Gale, D. (2004). Competition and Financial Stability. Journal of Money, Credit, and Banking. https://doi.org/10.1353/mcb.2004.0038

Amano, R. A., \& Van Norden, S. (1998). Exchange rates and oil prices. Review of International Economics. https://doi.org/10.1111/14679396.00136

Ball, L. (1999). Efficient rules for monetary policy. International Finance. https://doi.org/10.1111/1468-2362.00019

Beauchamp, J. J., \& Olson, J. S. (1973). Corrections for Bias in Regression Estimates After Logarithmic Transformation. Ecology. https://doi.org/10.2307/1934208

Beckmann, J., Czudaj, R. L., \& Arora, V. (2020). The relationship between oil prices and exchange rates: Revisiting theory and evidence. Energy Economics. https://doi.org/10.1016/j.eneco.2020.104772

Bjørnland, H. C., \& Halvorsen, J. I. (2014). How does monetary policy respond to exchange rate movements? New international evidence. Oxford
Bulletin of Economics and Statistics.

https://doi.org/10.1111/obes.12014

Cassino, E., Oxley, D., \& others. (2013). How Does the Exchange Rate Affect the Real Economy? A Literature Survey. Wellington, New Zealand Treasury Working Paper.

Clarida, R., Galí, J., \& Gertler, M. (1998). Monetary policy rules in practice some international evidence. European Economic Review. https://doi.org/10.1016/S0014-2921(98)00016-6

Égert, B., Drine, I., Lommatzsch, K., \& Rault, C. (2003). The Balassa-Samuelson effect in Central and Eastern Europe: Myth or reality? Journal of Comparative Economics. https://doi.org/10.1016/S0147-5967(03)00051-9

Gan, C., Lee, M., Au Yong, H. H., \& Zhang, J. (2006). Macroeconomic variables and stock market interactions: New Zealand evidence. Investment Management and Financial Innovations.

Gujarati, D. N. (2004). Basic Econometrics 4th Edition. In Tata McGraw-Hill. https://doi.org/10.1126/science.1186874

Hassan, S. A., \& Zaman, K. (2012). Effect of oil prices on trade balance: New insights into the cointegration relationship from Pakistan. Economic Modelling. https://doi.org/10.1016/j.econmod.2012.07.006

Jääskelä, J. P., \& Jennings, D. (2011). Monetary policy and the exchange rate: Evaluation of VAR models. Journal of International Money and Finance. https://doi.org/10.1016/j.jimonfin.2011.06.014 Juselius, K. (2006). The Cointegrated VAR 
Model:Methodology and Applications. In Book. https://doi.org/10.1093/acrefore/9780190625979 .013 .247

Kamin, S. B., \& Klau, M. (2003). A multi-country comparison of the linkages between inflation and exchange rate competitiveness. International Journal of Finance and Economics. https://doi.org/10.1002/ijfe.205

Keating, J. W. (1990). Identifying VAR models under rational expectations. Journal of Monetary Economics. https://doi.org/10.1016/03043932(90)90063-A

Kočenda, E., \& Valachy, J. (2006). Exchange rate volatility and regime change: A Visegrad comparison. Journal of Comparative Economics. https://doi.org/10.1016/j.jce.2006.07.003

Lubik, T. A., \& Schorfheide, F. (2007). Do central banks respond to exchange rate movements? A structural investigation. Journal of Monetary Economics. https://doi.org/10.1016/j.jmoneco.2006.01.009

Mohd, W., Abdoh, Y. M., Hafizha, N., Yusuf, M., Azreen, S., Zulkifli, M., Bulot, N., \& Ibrahim, J. (2016). Macroeconomic Factors That Influence Exchange Rate Fluctuation in ASEAN Countries. International Academic Research Journal of Social Science.

Nouira, R., \& Sekkat, K. (2012). Desperately seeking the positive impact of undervaluation on growth. Journal of Macroeconomics. https://doi.org/10.1016/j.jmacro.2011.12.002

Olomola, P. A., \& Adejumo, A. V. (2006). Oil price shock and macroeconmic economic activity in
Nigeria. International Research Journal of Finance and Economics.

Ramasamy, R., \& Abar, S. K. (2015). Influence of Macroeconomic Variables on Exchange Rates. Journal of Economics, Business and Management. https://doi.org/10.7763/joebm.2015.v3.194

Rodrik, D. (2008). The real exchange rate and economic growth. Brookings Papers on Economic Activity.

Shapiro, A. C., \& Hanouna, P. (2019). Multinational Financial Management. John Wiley \& Sons.

Svensson, L. E. O. (2000). Open-economy inflation targeting. Journal of International Economics. https://doi.org/10.1016/S0022-1996(98)00078-6

Tiwari, A. K., \& Olayeni, O. R. (2013). Oil prices and trade balance: A wavelet based analysis for India. Economics Bulletin.

Uddin, G. S., Tiwari, A. K., Arouri, M., \& Teulon, F. (2013). On the relationship between oil price and exchange rates: A wavelet analysis.

Economic Modelling.

https://doi.org/10.1016/j.econmod.2013.07.035

Yang, L., Cai, X. J., \& Hamori, S. (2017). Does the crude oil price influence the exchange rates of oil-importing and oil-exporting countries differently? A wavelet coherence analysis. International Review of Economics and Finance. https://doi.org/10.1016/j.iref.2017.03.015 